\title{
Neonatal airway anomaly: vallecular cyst
}

\author{
Collin F Mulcahy, ${ }^{1}$ Srijaya K Reddy, ${ }^{2}$ Emily E Wikner, ${ }^{3}$ Pamela A Mudd ${ }^{4}$
}

${ }^{1}$ Division of Otolaryngology, The George Washington University School of Medicine and Health Sciences, Washington, DC, USA ${ }^{2}$ Division of Anesthesiology, Pain and Perioperative Medicine, Children's National Health System, Washington, DC, USA ${ }^{3}$ School of Medicine and Health Sciences, The George Washington University, Washington, DC, USA

${ }^{4}$ Division of Otolaryngology, Children's National Health System, Washington, DC, USA

\section{Correspondence to} Dr Srijaya K Reddy, sreddy@cnmc.org

Accepted 7 November 2017

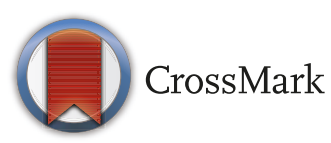

To cite: Mulcahy CF, Reddy SK, Wikner EE, et al. BMJ Case Rep Published Online First: [please include Day Month Year]. doi:10.1136/bcr-2017223082

\section{DESCRIPTION}

Neonatal laryngeal cysts are an uncommon but recognised cause of inspiratory stridor and respiratory distress in infants. Although a small cyst may be asymptomatic, due to the anatomical location and the small size of an infant's respiratory tract, larger cysts may cause acute airway obstruction. ${ }^{1}$ Affected infants typically display symptoms within the first week of life, which include inspiratory stridor, respiratory distress or feeding difficulties. Congenital vallecular cysts, also known as mucus retention cysts, may arise from the mucosal surface of the true vocal fold, epiglottis or vallecula. ${ }^{2}$ Vallecular cysts are particularly dangerous as they may cause posterior displacement of the supraglottis, causing collapse of the airway during inspiration leading to respiratory compromise. Additionally, several reports have documented an association between laryngomalacia and vallecular cysts. ${ }^{3}$ Diagnosis is typically obtained through flexible nasopharyngolaryngoscopy, and endoscopic marsupialisation is the recommended surgical approach in infants with a good long-term prognosis.

A 3-day-old full term neonate presented with stridor at an outside institution underwent a flexible fibre optic laryngoscopy that revealed an airway mass that would 'ball valve' and obstruct the laryngeal inlet before being transferred to our hospital. On initial evaluation by our team, the patient had increased work of breathing with abdominal retractions and inspiratory stridor when awake and supine, but had quiet breathing in the prone position. On day of life (DOL) 4, the patient was taken to the operating room for a diagnostic direct laryngoscopy

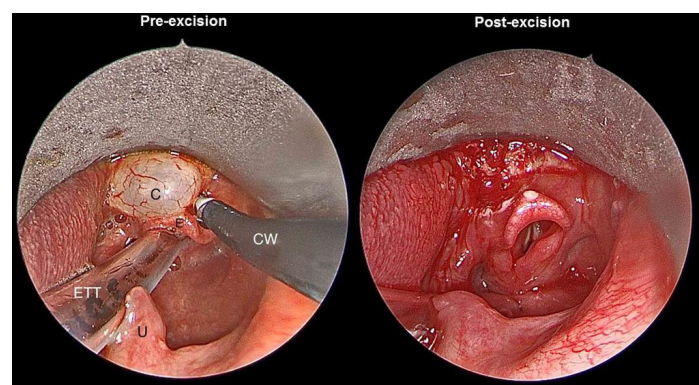

Figure 1 The pre-excision image depicts the vallecular cyst (C), endotracheal tube (ETT), uvula (U), coblator wand $(\mathrm{CW})$ and epiglottis $(\mathrm{E})$. The image on the right illustrates the airway after the cyst had been completely excised.

\section{Learning points}

- Awareness of structural airway abnormalities (ie, cysts or masses) and prompt direct visualisation with a prepared surgical plan is important in treating neonatal airway anomalies.

- It is important to pay close attention to coexisting airway abnormalities, especially in the setting of slower than expected clinical improvement after the initial abnormality is surgically treated.

and bronchoscopy with excision of cyst. A $6 \mathrm{~mm}$ mucous-filled cyst was found in the left/central portion of the vallecula (figure 1). The patient was found to also have secondary laryngomalacia from mass effect. After laryngoscopy and bronchoscopy revealed no further abnormalities, the patient was placed into suspension laryngoscopy. The vallecular cyst was grasped and the microlaryngeal coblation wand was used to excise the cyst at its base. The cyst was completely excised and the secondary laryngomalacia appeared to improve (figure 1). Postoperatively, the patient's clinical course was slow to improve subsequently requiring a supraglottoplasty that was performed on DOL 16. At that time, there was no evidence of cyst recurrence, the patient had an uneventful postoperative course and the patient was discharged on DOL 19.

Contributors $\mathrm{CM}$ and EEW were responsible for the initial manuscript preparation. SKR was responsible for editing and preparing the manuscript for submission to journal. PAM was responsible for providing the images for this manuscript. All authors approved the final manuscript.

Competing interests None declared.

Patient consent Obtained.

Provenance and peer review Not commissioned; externally peer reviewed.

(C) BMJ Publishing Group Ltd (unless otherwise stated in the text of the article) 2017. All rights reserved. No commercial use is permitted unless otherwise expressly granted.

\section{REFERENCES}

1 Suzuki J, Hashimoto S, Watanabe K, et al. Congenital vallecular cyst in an infant: case report and review of 52 recent cases. J Laryngol Otol 2011;125:1199-203.

2 Arens C, Glanz H, Kleinsasser O. Clinical and morphological aspects of laryngeal cysts. Eur Arch Otorhinolaryngol 1997;254:430-6.

3 Yao $\mathrm{TC}$, Chiu CY, Wu KC, et al. Failure to thrive caused by the coexistence of vallecular cyst, laryngomalacia and gastroesophageal reflux in an infant. Int J Pediatr Otorhinolaryngol 2004;68:1459-64. 
Copyright 2017 BMJ Publishing Group. All rights reserved. For permission to reuse any of this content visit http://group.bmj.com/group/rights-licensing/permissions.

BMJ Case Report Fellows may re-use this article for personal use and teaching without any further permission.

Become a Fellow of BMJ Case Reports today and you can:

- Submit as many cases as you like

- Enjoy fast sympathetic peer review and rapid publication of accepted articles

Access all the published articles

- Re-use any of the published material for personal use and teaching without further permission

For information on Institutional Fellowships contact consortiasales@bmjgroup.com

Visit casereports.bmj.com for more articles like this and to become a Fellow 